\title{
KEADILAN BERDASARKAN KOTA PERLINDUNGAN DALAM ULANGAN 4:41-43 DAN 19:1-13
}

\author{
Aeron Frior Sihombing1, Barnabas Ludji ${ }^{2}$, Pelita H. Surbakti ${ }^{3}$ \\ STT SAPPI Ciranjang ${ }^{1}$, STT Tipanas $^{2} 3$ \\ aeronsihombing@gmail.com¹ ${ }^{\text {barnabasludji28854@gmail.com², }}$ \\ pelitasurbakti@yahoo.com ${ }^{3}$
}

\begin{abstract}
ABSTRAK
Kota perlindungan dalam Ulangan 4:41-43 dan 19:1-13 merupakan suatu tempat untuk mencari suaka atau perlindunga, agar tidak tertumpah darah yang tidak bersalah di tanah yang diberikan oleh Allah bagi orang Israel. Penelitian ini dilakukan dengan metode historis kritis. Dengan demikian, hasil dari penelitian ini adalah kota perlindungan merupakan perwujudan dari keadilan sosial.
\end{abstract}

Kata-kata kunci: keadilan, kota-kota perlindungan, Ulangan.

\section{ABSTRACT}

The city of refuge in Deuteronomy 4:41-43 and 19:1-13 is a place to seek asylum or protection, so that innocent blood is not spilled on the land that God gave to the Israelites. This research was conducted using a critical historical method. Thus, the result of this research shows that cities of refuge are the embodiment of social justice.

Keywords: Justice, cities of refuge, Deuteronomy.

\section{PENDAHULUAN}

Jeffrey Stackert mengungkapkan bahwa para sarjana masa kini memperhatikan hubungan dalam tubuh dari Pentateukh, meskipun tidak memiliki konsensus yang sama (Stackert 2006:23). Misalnya dalam kasus hukum perlindungan (asylum) terdapat perbedaan pandangan mengenai kota perlindungan dalam Pentateukh di dalam mereka sendiri (Kel. 21:12-14, Ul. 19:1-13 dan Bil. 35:9-34) (Stackert 2006:23). Baginya, ketidaksepakatan ini berasal dari pengembangan konseptualisasi asylum terhadap interpretasi yang khas dalam berbagai hukum dan termasuk perdebatan mengenai eksistensi dan natur dari hubungan literatur (sastra) di antara teks- teks ini (Stackert 2006:23). 
Pertanyaan yang diajukan oleh Stackert adalah apakah natur kotaperlindungan yang telah ditetapkan oleh berbagai hukum? Apakah kota perlindungan sebagai institusi aktual yang telah dilakukan di Israel kuno, ataukah itu tidak dipraktekkan, sebagai ciptaan dari literatur atau sastra dari redaktur? Jika kota perlindungan dilakukan atau dijalankan di Israel, apakah hukum Pentateukh secara akurat merefleksikan budaya historis ini? Dan, apakah kota perlindungan merupakan suatu institusi historis atau tidak, apakah yang memotivasi perbedaan undang-undang dalam biblika mengenai model kota perlindungan? Apakah kronologis perbedaan dari hukum kota perlindungan? Apakah ada bukti internal pengembangan di dalam teks individual yang menawarkan petunjuk interpretasi atau makna historis? Jika demikian, teks yang manakah yang menyediakan sumber bagi komposisi selanjutnya dan bagaimanakah penulis teks terakhir mengunakan dan merevisi sumbernya? (Stackert 2006:23)

Metode yang digunakan dalam penelitian ini adalah metode historis kritis (bistory criticism method). Metode historis kritis merupakan suatu pencarian makna apa yang dikatakan oleh teks, seperti apa yang dikatakan oleh penulis dan pembaca pertama. Hal ini bertujuan untuk memahami apa yang sebenarnya yang dikatakan oleh teks tersebut (Krentz 1975). Ini dilakukan untuk mengatasi kesenjangan ruang dan waktu antara teks, penulis dan pembaca untuk menemukan maksud asli penulis teks tersebut tanpa prasangka pembacanya. Hal ini dilakukan untuk mencari kebenaran yang objektif (Hardiman 2015:36).

\section{KRITIK SUMBER 4:41-43 DAN 19:1-13}

Sumber Ulangan 19:1-13 menurut von Rad (Gerhard von Rad 1966:12-14), Bernard Levinson (Levinson 1977:3-22), Otto (Otto 1996:112)1 adalah berasal dari Kitab Perjanjian. Senada dengan Stackert bahwa19:1-13 adalah bersal dari Keluaran 21:12-24. Ia melihatnya dari korespondensi leksikal di antara kedua teks tersebut (Otto 1996:32-40). Misalnya adalah Keluaran 21:13, menggunakan klausade "שמהאשר "to which he may flee" "ke mana ia dapat lari" yang pararel dengan tepatnya dengan Ulangan 19:4. Selain itu, berbagai variasi muncul beberapa kali dalam Ulangan 19:1-13. Misalnya Ulangan 19:3, "It shall be for any killer to flee there"

${ }^{1}$ Bagi Otto, redaktur pra-pembuangan memodenisasi Kitab Perjanjian. 
(19:5; 19:11) (Stackert 2006:23-40). ${ }^{2}$ Namun, Stackert masih belum membahas darimanakah sumber Kitab Perjanjian, secara khusus adalah mengenai tempat perlindungan dalam Keluaran 21:12-14. Ia membahas secara khusus isu mengenai 'tempat' perlindungan dalam Keluaran 21:12-14 dan membandingkannya dengan Ulangan 19:1-13. Pertanyaannya adalah dari manakah sumber Keluaran 21:12-14? Dengan demikian, perbedaannya akan ditemukan dengan sumber " $D$ " dalam Ulangan 19:1-13.

Apabila menilik dari kata Allah אלהים dari sumber Kitab Perjanjian (Kel. 21:13), maka ada kemungkinan bahwa ia adalah dari sumber E yang berasal Kerajaan Utara yang terjadi sekitar abad 9-8 SM (Barnabas Ludji 2009:52). Blommendaal mengatakan bahwa Kitab Perjanjian ini barangkali berasal dari masa hakim-hakim, di mana bangsa Israel pada masa tersebut melakukan pertanian dan peternakan (Blommendaal 1985:48). Maka, peraturan atau ketetapan dalam Kitab Perjanjian tersebut masih cukup sederhana dan belum kompleks seperti yang terjadi dalam hukum Deuteronomic yang kompleks pada masa monarki (Ul. 19:1 13).

Dengan demikian, pengaruh Kerajaan Utara sangat besar pada "Kitab Perjanjian", di mana di sana telah terjadi ketidakadilan sosial yang cukup menyolok seperti yang diungkapkan oleh nabi Amos di sana. Apabila kitab ini ditemukan oleh Saphan pada masa pemerintahan Yosia, kemungkinan besar adalah ini dikembangkan pada masa pemerintahan raja Yosia untuk mendukung reformasinya (2Raj. 22-23) (Levinson 1977:9). ${ }^{3}$ Pandangan ini senada dengan Cairns bahwa Kitab Perjanjian (Kel. 21:13) adalah dari sumber E, di mana redaktur Deuteronomi menggabungkan E dan Y serta menggembangkannya pada abad ke-7 SM (Cairns 1992:5-6).

Menurut Kevin Mattison, kota perlindungan dalam Ulangan 19:1-13 berbeda dengan Bilangan 35:9-34 (Mattison 2016:29-45). Perbedaannya cukup kelihatan, karena kedua teks tersebut berasal dari dua sumber yang berbeda,

2 Dengan demikian, Stackert menyimpulkan bahwa sumber Ulangan 19:1-13 adalah dari Keluaran 21:12-14. Redaktur (penulis) kitab Ulangan telah mengunakan sumber dari Kitab Perjanjian, bahkan ia merevisi dan mendaur ulang kembali sesuai dengan kebutuhannya. Stackert mengatakan bahwa: 1) ia secara langsung membawa teks Kitab Perjanjian tanpa merevisi rumusan legalnya (hukum); 2) ia secara langsung membawa isi dengan revisi rumusan legalnya; 3) ia merevisi secara kreatif isi dan menambahkan ragam redakturnya.

${ }^{3}$ Levinson mengatakan bahwa sentralisasi dan pemurnian kultus terjadi pada tahun 622 SM, seperti yang dinarasikan dalam 2 Raja-raja 22-23. 
sehingga latar belakang pemikiran mengakibatkan perbedaan tujuan atau maksud dari kota perlindungan tersebut. Bagi Mattison, Bilangan 35:9-34 berasal dari sumber Holiness Code $(\mathrm{H})$ dan bukan Priestly $(\mathrm{P})$. Karena, teks P melampaui H (Im. 17-26), di mana Holiness Legastion berdasarkan bentuk $\mathrm{H}$, tetapi tidak berdasarkan $\mathrm{P}$, sebab posisi mengenai etika dan ritual saling berdampingan dan berinteraksi dengan sumber teks P dan bukan non-P (Mattison 2016:30).

Persamaan antara Ulangan 19:1-3 dan Bilangan 35:9-34 adalah berbicara mengenai kota perlindungan (enam kota) bagi darah yang tertumpah, karena tidak disengaja. Perbedaan konsepsinya adalah dalam pertumpahan darah, di mana menurut pandangan $\mathrm{D}$, pertumpahan darah yang salah adalah bila direncanakan atau disengaja (Mattison 2016:30). Sementara itu bagi H, apabila darah sudah tertumpah maka ia sudah bersalah, meskipun disengaja atau tidak disengaja (Bil. 35:31-33). Hal ini telah mengakibatkan pencemaran atas tanah (Mattison 2016:35). Namun, Mattison masih belum menjelaskan secara tegas letak perbedaan antara sumber P dan $\mathrm{H}$, di mana mereka masih dari latar belakang yang sama. Pertanyaan yang muncul adalah bagaimana bisa membedakan antara sumber $\mathrm{P}$ dan $\mathrm{H}$ ?

Hal yang penting adalah mengapa ada dua teks mengenai kota perlindungan dalam kitab Deuteronomi, yaitu 4:41-43 dan 19:1-13. Mengapa perlu mengulanginya sebanyak dua kali? Apakah ini tidak saling tumpang tindih? Weinfeld mengatakan bahwa ini menjadi masalah yang cukup rumit (Weinfeld 1971:230-33). Di sana, Israel diperintahkan untuk memisahkan tiga kota perlindungan setelah penaklukan dan pendudukan keseluruhan tanah (ay. 1-2), dan tidak ada disebutkan kota perlindungan di Transjordan. Menurut Weinfeld, ada yang berargumen bahwa kota perlindungan di Transjordan tidak disebutkan dalam Ulangan 19, karena ini sudah ada dalam Ulangan 4:41-43, tetapi sukar untuk menjelaskan penghindaran terhadap berbagai petunjuk terhadap mereka dalam hukum secara umum mengenai kota perlindungan (Weinfeld 1971:233).

Bagi Weinfeld, Ulangan 4:41-45 menggunakan bahasa Deuteronomi dan bukan Bilangan (bukan kitab undang-undang priestly), dan kecuali kalau ia merupakan tambahan post-Deuteronomic yang kemudian-suatu tambahan di mana tidak ada buktinya-mungkin mungkin dapat diasumsikan bahwa Ulangan 19 presuposisikan pemisahan kota perlindungan di Transjordan oleh Musa, seperti yang diutarakan dalam 4:41-43 (Weinfeld 1971:233).

Jawaban Weinfeld masih belum memuaskan mengenai perbedaan Ulangan 4:41-43 dan 19:1-13. Berbanding terbalik dengan J. Blommendaal bahwa Ulangan 
4:41-43 bukanlah berasal dari sumber D seperti yang diungkapkan oleh Weinfeld. Baginya, sumber 4:41-43 berasal dari sumber P (Blommendaal 1985:63). Namun, Blommendaal tidak menjelaskan alasan atau argumentasi mengenai sumber $\mathrm{P}$ dalam 4:41-43. Akan tetapi, argumentasi Weinfeld lebih masuk akal, bahwa bahasa 4:41-43 merupakan ciri khas dari sumber D.

\section{KRITIK REDAKSI}

Römer berpandangan bahwa gulungan Deuteronomistic history bukanlah suatu proses yang terjadi sekali jadi atau dilakukan oleh satu redaktur. Prosesnya cukup panjang dan dilakukan oleh beberapa redaktur, sehingga ia memiliki beberapa redaktur meski dari dalam group atau kelompok yang sama yaitu Deuteronomistic school (Thomas 2007:67-106). Salah satunya adalah edisi pertama dari Deuteronomic bistory ini adalah 4:41-43 dan 19:1-13.4

Otto mengatakan bahwa latar belakang atau konteks sistem hukum dari 19:1-13 ini adalah Assyrian (Otto 1996:117). Senada dengan Römerbahwa konteks 4:41-43 dan 19:1-13 berasal dari konteks Assyrian (Thomas 2007:73). Redaktur yaitu Deuteronomic school ini berada di bawah pemerintahan raja Yosia seperti yang diekspresikan dalam 2 Raja-raja 22-23 (Thomas 2007:73). Ini merupakan propaganda yang dilakukan oleh Yosia untuk mendukungnya sebagai raja Yehuda maupun Israel (utara) yang sudah ditaklukkan, di mana ini merupakan suatu anti Assyrian (Thomas 2007:45-65). Römer mengatakan bahwa bagian ini terlihat dari tujuan raja Yosia yang digambarkan di antara raja-raja Yehuda, sebagai "raja Daud yang baru” (2Raj. 23:25) (Thomas 2007:69). Para pejabat monarki menyebutkannya sebagai figur atau tokoh yang memimpin dalam Deuteronomist. Bagi Römer, akhir abad ketujuh Sebelum Masehi merupakan setting sejarah dari kelahiran atau kemunculan dari Deuteronomistic literature (Thomas 2007:69).

Sumber Ulangan 4:41-43 dan 19:1-13 adalah sama-sama dari sumber D, di mana ia adalah berasal dari hukum Deuteronomic. Namun, pertanyaannya adalah mengapa ada topik yang sama dengan sumber yang sama, tetapi keduanya ada

4Periode Assyrian setelah tahun 620 SM, yang ideologinya adalah propaganda untuk membangkitkan nasionalisme yaitu mendukung reformasi Yosia, seperti sentralisasi kultus maupun politik yang ingin independen; 2) Lapisan selanjutnya adalah NeoBabylonian 539 SM (kebangkitan kuasa Cyrus), di mana ideologinya adalah krisis identitas Yehuda, akibat dari hancurnya monarki dan dideportasi baik yang diperlihatkan dalam deportasi Assyrian dan juga Neo-Babylonian; 3) periode Persia. 
perbedaan? Apakah kedua hal ini bukanlah sesuatu yang tumpang tindih atau ada sesuatu maksud lain dari penempatan kedua teks tersebut?

Ulangan 4:41-43 dan 19:1-13 merupakan dua redaktur yang berbeda. Karena, tidak mungkin redaktur yang sama memasukkan tema yang sama dengan gaya sastra yang berbeda. Pandangan ini didukung oleh Römer yang menyatakan bahwa dua prolog dalam pasal 1-3 (4) dan 5-11 dan beberapa kesimpulan dalam pasal 26, 27-8, dan 30-34 adalah berbeda dengan pasal 12-26. Pasal 12-26, bagi Römer tidak memproposisikan pasal 1-4 dan 9-10 (Thomas 2007:73). Di samping itu, Nicolsky dalam Feigberg mengatakan lebih tegas bahwa 4:41-43 lebih dahulu daripada 19:1-13, di mana 19:8-10, adalah tambahan dari redaktur yang kemudian, karena ia membuat jeda atau memotong antara ayat 7 dan 11, di mana redaktur tersebut tidak setuju dengan 4:41-43 yang hanya menempatkan tiga kota perlindungan (Feinberg 1947:35). Menurutnya, redaktur menambahkan 19:8-10 dengan tujuanmengharmonikannya dengan Priest Code (Bil. 35:13, 14; Yos. 20:7, 8) (Feinberg 1947:35). Baginya, 19:1-13 merupakan kelanjutan dari reformasi Deuteronomic pada tahun 621 SM.

Demikian halnya dengan Römer, 19:1-13 merupakan hasil redaksi yang belakangan. Misalnya adalah numeruswechsel, yaitu perubahan bentuk kata ganti orang pertama kedua tunggal dan kedua jamak terhadap penerima perintah tersebut (Thomas 2007:73). Ini menunjukkan bahwa ini adalah redaksi yang belakangan, untuk pengembangan dari 4:41-43. Tujuannya adalah untuk mendukung sentralisasi raja Yosia.

\section{PENDALAMAN TEKS}

1. Ulangan 19:1-3 dengan Keluaran 21:12-14

Kitab Perjanjian (Kel. 21:12-14)merupakan salah satu sumber dari kitab Ulangan(Kel. 21:12).Dengan demikian, ada persamaan dan perbedaannya dengan kitab Ulangan 19:1-13.

a. Persamaan Ulangan 19:1-13 dengan Keluaran 21:12-14

Persamaannya: 1)Ulangan 19:4b dengan Keluaran 21:13, yaitu bahwa apabila seseorang yang tidak sengaja membunuh atau menumpahkan darah seseorang, maka ia harus pergi atau lari secepatnya di tempat perlindungan yang 
telah ditunjuk. Tanpa diketahui atau knowledge, בבלי דעת (terjemahan sendiri). LAI menerjemahkannya dengan kata "tidak disengaja". KJV ignorantly, RSV, NAS, dan NKJ unintentionally. Kata yang lebih dekat terjemahannya adalah RSV, NAS, NKJ maupun LAI, yaitu tidak disengaja atau dengan terjemahan hurufiah yaitu "tidak diketahui".

2) Pembunuhan yang dilakukan karena benci (LAI)שנא , ASV, KJV, NAS, NIV, RSV: hate dalam Ulangan 19:11 dan sementara itu Keluaran 21:14 yaitu dengan angkara, maka ia akan dihukum mati. Kata angkara ארמה dalam terjemahan LAI, sementara itu terjemahan dari ASV, KJV, NAS: presumptuously; NIV, schemes; RSV, willfully.Terjemahan yang lebih mendekati dengan teks Ibraninya adalah terjemahan NIV yaitu schemas yaitu hati-hati. Dengan demikian, unsur perencanaan terdapat di dalamnya.

3) Perintah untuk menyediakan tempatantuk perlindungan dalam Keluaran 21:13, dan Ulangan 19:1,yרים תבדילשלוש,yaitu tiga kota untuk perlindungan. Ketetapan ini dilakukan sebelum masuk ke tanah Kanaan, di mana bangsa Israel pada dalam Keluaran berada di Sinai (Kel. 19:1), sementara dalam Ulangan di Horeb (Ul. 9:7).

\section{b. Perbedaan antara Ulangan 19:1-13 dengan Keluaran 21:12-14}

Teks-teks dalam Ulangan 19:1-13 yang tidak ada dalam Keluaran 21:12-14 adalah: 1)asylum dalam Keluaran 21:13 adalah suatu "tempat"מקום, di mana pada ayat 14 disebut mezbahatautempat suci lokal. Sangat berbeda dengan Ulangan 19:2, yaitu asylum disediakan di dalam "tiga kota" עריםשלוש. Bahkan dalam ayat 8-9, ada penambahan tiga kota perlindungan lagi bila ada penambahan atau perluasan wilayah,יהוה אלהידואם-ירחיב.Hal inilah yang menjadi isu hangat dalam asylum. Stackert berpandangan bahwa redaktur Ulangan mengembangkan asylum "tempat" menjadi tiga kota perlindungan dengan penambahannya (Thomas 2007:29-40). Moshe Greenberg dan Pamela Barmash (Thomas 2007:23-40) menolak pandangan ini bahwa redaktur Ulangan tidak mengembangkan hal tersebut.Karena, bagi Greenberg kota perlindungan dalam Ulangan merupakan refleksidari kitab Bilangan 35, di mana kota perlindungan adalah kota-kota yang diwarisi oleh suku Lewi di tempat suci lokal (Greenberg 1959:131). Stackert menolaknya, karena sumber Ulangan adalah berasal dari Kitab Perjanjian (Stackert 2006:30).

2)Dalam Keluaran 21:13 mengenai pembunuhan yang tidak disengaja, frasediterangkan sebagai bagian dari rencana Tuhan. Redaktur 
Kitab Perjanjian mengunakan kata penghubung l, yang artinya "dan" atau tetapi, sementara LAI menerjemahkan "melainkan". Frasedאנהלידווהאלהיםsepertinya ditambahkan oleh redaktur Kitab Perjanjian, karena ia tidak berusaha memotong dua frase dalam Keluaran 13. Ini adalah motif pembunuhan yang tidak disengaja dalam Kitab Perjanjian.

Berbeda dengan Ulangan 19:4, motifnya bukanlah karena bagian rencana Tuhan, melainkan memang pembunuhan yang tidak disengaja, לא־שנא לווהואבבל־דעתאת־רעהויכהאשר.Misalnya, ketika seseorang sedang memotong kayu, mata kapaknya tidak sengaja terlepas, sehingga mengenai orang lain (ay. 5).Ini menunjukkan bahwa motifnya memang benar-benar tidak disengaja, dengan memberikan contoh kasus khusus tersebut.

3)Frase darah panas "כי־יחמלבבו"dalam Ulangan 19:6 menunjukkan bahwa ada pembalasan "hutang darah" atau "tebusan darah" dengan hati panas. Sementara itu, dalam Kitab Perjanjian di Keluaran 21:12-14 tidak ada sebutkan atau dijelaskan. Dengan demikian, motif pembunuhan di sini lebih kelihatan lebih jelas atau nyata.

4) Frase "perluasan daerah" "את־גבלךיהוהאלהיךאם-ירחיב"dalam Ulangan 19:8, tidak terdapat dalam Keluaran 21:12-14. "Perluasan daerah" ini erat kaitannya bagaimana teroterial Yerusalem "Kerajaan Yehuda" dikembangkan. Dengan demikian, ini dapat dikatakan adalah pada masa setelah monarki, di mana kemungkinan Israel Utara sudah dihancurkan, sehingga dapat kembali disatukan dengan Israel Selatan, di masa kerajaan Yosia maupun setelah pembuangan. "Perluasan daerah" merupakan bagian dari perjanjian Tuhan Allah dengan bapa leluhur Israel, sehingga bila Tuhan Allah telah menepati janji-Nya, maka Israel juga harus melakukan perintah Allah, yaitu dengan menambahkan kota-kota perlindungan sebanyak tiga kali.

5) Kata "Allah"“'והאלהים"digunakan dalam Keluaran 21:13. Ini berbeda dengan Ulangan 19:1, 2, 3, 8, 9, 10, di mana kata yang digunakan adalah dalam terjemahan LAI “Tuhan Allahmu"“"יהוה אלהיך" KJV “LORD thy God”, berbeda dengan NAS, NIV, RSV, “LORD your God”.Hal ini menunjukkan bahwa redaktur Ulangan menggembangkan Kitab Perjanjian dengan menggabungkan dua tradisi yaitu Elohist dan Yahwist (Wellhausen et al. 2013:13). Salah satu tujuannya adalah sebagai legitimasi dari tulisan redakturnya. Dengan demikian, Ulangan 19:1-13 ini merupakan terjadi belakangan setelah Kitab Perjanjian. 
6) Frase "hutang darah" עליך דמים, di Ulangan 19:10, dalam terjemahan LAI, berbeda dengan ASV dan KJV so blood be upon thee, NAS: bloodguiltiness be on you. NIV:so that you will not be guilty of bloodshed. RSV: so the guilt of bloodshed be upon you. Lebih dekat terjemahan dari LAI, hutang darah. Terjemahan hurufiah dari bahasa Ibrani adalah "melawan darah". Ini cukup dekat dengan Priestly Code, yaitu berkaitan dengan darah.Bagian ini tidak ada dalam Kitab Perjanjian yaitu Keluaran 21:12-14.

7)Ulangan 19:12 terdapatipara tua-tua kota" dalam terjemahan LAI; ASV, KJV, NAS, NIV, RSV adalah elders. Sedangkan di dalam Keluaran 21:12-14 tidak ada terdapat "para tua-tua kota". Tujuannya adalah untuk mengadili orang yang melakukan pembunuhan dengan motif membenciwנש(ay.11), yang disertai pembunuhan terencana. Dengan demikian, di sini sudah ada pengadilan lokal yang dilakukan oleh para profesional, yaitu para tua-tua. Hal ini disertai dengan saksisaksi mata (ay. 15-21).

\section{Ulangan 19:1-13 dengan Bilangan 35:9-34}

a. Persamaan Ulangan 19:1-13 dengan Bilangan 35:9-34

1) Penuntut tebusan darah (LAI), ASV, KJV, NAS, NIV, RSV

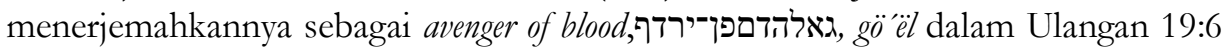
dan Bilangan 35:12 sama-sama dapat menuntut balas sebagai terhadap pembunuh keluarganya. Hal ini dapat dilakukan bila pembunuh yang tidak disengaja tersebut berada di luar kota perlindungan.

2) Kota perlindungan dalam Ulangan 19:2, 9 dan Bilangan 35:13 adalah disediakan sebanyak enam kota perlindungan. Hal ini merupakan perintah yang diberikan oleh Tuhan, Allah.

3) Ulangan 19:11-13 dan Bilangan 35:16-21 menghukum orang yang membunuh dengan motif benci maupun permusuhan. Pelaku pembunuh yang berencana tersebut akan dihukum mati.

b. Perbedaan Ulangan 19:1-13 dengan Bilangan 35:9-34

1) Kota perlindungan yang dikhususkan dalam Ulangan 19:2 adalah tiga kota ארצךבתוךתבדיל לךעריםשלוש (ay. 2), dan akan ditambahkan tiga lagi bila

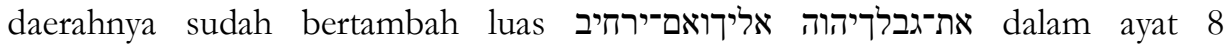
dan האלהעל השלשעריםשלשעודויספת לך (ay. 8-9). Berbeda dengan Bilangan 35:13, 
תהיינה לכםמקלטשש־עריתתנווהעריםאשר. Ini menunjukkan bahwa teks ini kemungkinan lebih muda daripada Ulangan 19:2, 8, 9. Perintah ini dibuat dikondisikan ketika tanah Israel sudah luas, sementara dalam Ulangan 19:2, 8, 9 tanahnya akan diperluas (Greenberg 1959:131-32).

2) Pengunaan kata TUHAN, Allah יהוה אלהיך digunakan oleh redaktur Ulangan 19:1, 2, 3, 8, 9, 10, di mana redaktur Ulangan 19 menggabungkan dua tradisi J (Selatan) dan E (Utara). Berbeda dengan Bilangan 35:9, 34, yang mengunakan kata TUHAN יהוה. Penggunaan kata ini dapat menunjukkan bahwa redaktur Bilangan 35: 9-34 berasal dari tradisi Selatan atau Yehuda (Stackert 2016:211).

3) Jarak kota perlindungan dalam Ulangan 19:3 harus ditentukan jaraknya, agar orang yang melakukan pembunuhan yang tidak disengaja dapat lari ke sana secepatnya את־גבול ארצךושלשתהדרךתכין לך. Agar, ia dapat diselamatkan dari pencari hutang darah. Bagian ini tidak ada dalam Bilangan 35:9-34.

4) Ulangan 19:5, memberikan contoh satu mengenai pembunuhan yang tidak disengaja, yaitu mengenai mata kapak yang terlepas dari gagangnya tanpa

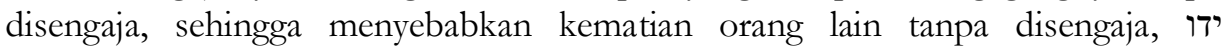
בגרזוונדחהלחטבעציםאת־רעהו ביערומתואשר יבאאת־רעהוומצמן־העץונשל הברזלהעץלכרת. Contoh kasus ini cukup sederhana, di mana cukup berbeda dengan Bilangan 35:22-23. Dalam teks ini, redaktur memberikan contoh yang lebih banyak yaitu sebanyak tiga contoh dan lebih lengkap dan kompleks. Contoh kasus pertama adalah dengan menumbuk (memukul) terjemahan LAIה הדפו, melemparkan sesuatu השליך, אבן, menjatuhkan batuinga menyebabkan kematian seseorang tanpa sengaja.

Demikian juga contoh mengenai pembunuhan yang disengaja dalam Ulangan 19:11 hanya ada satu contoh. Motifnya adalah benci שנא, kemudian ia menunggunya terjemahan ASV, KJV, NAS, NIV, RSV: lie in wait for him, שרב, sehingga melakukan pembunuhan yang berencana, sebab ia menunggu waktu yang tepat. Sementara itu, Bilangan 35:16-21 memberikan beberapa contoh pembunuhan disengaja dengan motif dua motif yaitu benci, sehingga ia

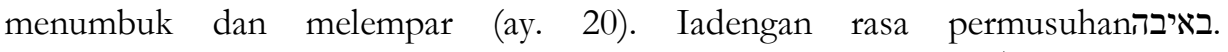
Iamemukulnya (ay. 21). Ia membunuh dengan benda besi ברזל, batu di ידבאבןואם (ay. 17), kayur. 18). 
Redaktur kitab Bilangan 35:16-21 menuliskan contoh yang lebih kompleks dan lengkap mengenai motivasi pembunuhan yang disengaja dan juga cara pembunuhannya. Hal ini menunjukkan bahwa kondisi sosial politik dari redaktur Bilangan 35:16-21 ini lebih maju peradabannya, sehingga dapat dikatakan ia kemungkinan sedikit lebih muda daripada Ulangan 19:11.

5) Pengadilan terhadap orang yang melakukan pembunuhan yang disengaja dalam Ulangan 19:12 adalah dilakukan oleh para tua-tua kotal. Sementara itu dalam Bilangan 35:24, pengadilan dilakukan oleh rapat umat.Hal yang menarik dari sini adalah Bilangan 35:24 kemungkinan adalah berasal dari sumber yang tertua, dan kemungkinan adalah dari P (Mattison 2016:29-30), ${ }^{5}$ sementara itu Ulangan 19:12 pengadilan dilakukan oleh yang profesional yaitu tuatua kota. Dengan demikian, kondisi sosial politik Ulangan 19:12 ini lebih maju atau kompleks daripada Bilangan 35:24.

6) Bagi Bilangan 35:33, darah tertumpah apakah karena disengaja atau tidak disengaja adalah dosa. Karena, darah yang tertumpah adalah ke atas tanah adalah mencemarkan negeri,את־האריץיחניפהואהדםבה כיאתםשר. Sementara itu bagi יהוה Ulangan 19:10, darah tertumpah karena pembunuhan yang tidak disengaja אלהיךאשרארצךבקרבדם נקיישפךולאדםנקי Hal yang terpenting adalah motifnya, yaitu bukan karena dendam, benci atau permusuhan (Mattison 2016:40-45).

Ketujuh, Bilangan 35:32, tidak boleh menerima uang tebusan atas pembunuh yang disengajalמקלטואל־עירלנוסכפרולא־תקח. Bagian ini tidak ada dalam Ulangan 19:1-13.

\section{Ulangan 19:1-13 dengan 4:41-43}

a. Persamaan Ulangan 19:1-13 dengan 4:41-43

Pertama, Ulangan 19:1-13 dan 4:41-43 merupakan penetapan kota perlindungan, secara khusus bagi orang yang tidak sengaja melakukan pembunuhan. Jadi, motifnya adalah "ketidaksengajaan" terjemahan LAI; ASV: unawares; KJV: ignorantly; NAS, NIV, RSV: unintentionally dalam 4:42. Namun, terjemahan bebas secara hurufiah adalah "ketidaktahuan", di mana ini lebih dekat dari teks asli dan tidak ada permusuhanwלשנ־, terjemahan LAI; ASV, KJV, NAS: hated; NIV: malice; RSV: enmity. Terjemahan LAI dalam 19:5

${ }^{5}$ Mattison mengatakan bahwa sumbernya adalah dari Holiness Code, di mana ini bagian dari $\mathrm{P}$. 
merupakan terjemahan hurufiah dan lebih dekat, sama halnya dengan ASV KJV, NAS.

b. Perbedaan Ulangan 19:1-13 dengan 4:41-43

1) Ulangan 19:1-13 merupakan perintah yang diberikan secara langsung kepada bangsa Israel melalui Musa,אלהידיהוהכי־יכרית. LAI menerjemahkannya "Apabila TUHAN, Allahmu" (ay. 1). Sementara itu, ASV: "When Jehovah thy God"; KJV: "When the LORD thy God"; NAS, NIV dan RSV: "When the LORD your". partikel penghubunghomonym כרת 2hiphil imperfect,kata ganti orang ketiga maskulin tunggal, "apabila, TUHAN, Allahmu”. Terjemahan ASV lebih hurufiah dari KJV, NAS, NIV maupun RSV, namun kata Elohim tidak diterjemahkan. Maka, lebih baik mengunakan terjemahan KJV, NAS, NIV maupun RSV.

Sementara itu, gaya penulisan 4:41-43 bukanlah dalam bentuk perintah secara langsung, melainkan resume dari 19:1-13. Karena 4:41-43 lebih singkat dari 19:1-13, maka situasi dalam 19:1-13 lebih kompleks daripada 4:41-43, hal ini ditunjukkan dari contoh kasusnya dengan menggunakan mengunakan כי, yaitu "jika/apabila" di awal kalimat. Bentuk ini menunjukkan kasuistik dari teks tersebut. Jadi, redaktur 19:1-13 menjabarkan, memperluas maupun mengembangkan 4:41-43.

2) 19:3 menetapkan bahwa jarak kota, agar tidak terlalu jauh, sehingga dapat dijangkau dan meminimalkan korban berjatuhan את־גבולושלשתהדרךתכין לך. Redaktur 19:3 mengembangkan bagian ini, di mana ini tidak ada dalam 4:41-43.

3) 19:5-6 memberikan satu contoh kasus mengenai pembunuhan yang tidak disengaja, seseorang yang sedang menebang kayu, di mana mata kapaknya tidak sengaja lepas dari gagangnya mengenai orang lain. בגרזוידועצים בגרוודועצים. Ini tidak ada dalam 4:41-43, di mana redaktur 19:5-6 mengambangkannya dari 4:41-43.

4) 19:6 menyinggung tentang penuntut tebusan darah (gang akan לבוכי-יחםהרצחאחריגאל הדפפן־ירדף.Ini merupakan tugas atau haknya sebagai wakil dari keluarganya yang telah meninggal tersebut. Bagian ini tidak terdapat dalam 4:41-43, sebab ini merupakan pengembangan dari redaktur 19:1-13.

5) 19:8-9: penambahan tiga kota perlindunganתשלש עריםלך עודויספירות (ay. 9),bila sudah ada perluasan wilayah את־גלךיהוה אלהיךואם־ירחיב (ay. 8).4:41-43 
tidak menyebutkan ada tambahan kota perlindungan, sehingga ia hanya menuliskan tiga kota perlindungan. Dengan demikian, redaktur 19:8-9 mengembangkannya dari 4:41-43 untuk tujuan teologisnya.

6) 19:10 terdapat tujuan dari kota perlindungan adalah agar tidak tercurah בקרב darah orang yang tidak bersalah di negeri yang diberikan oleh Tuhan, Allah, בקרב.Bagian ini tidak terdapat dalam 4:41-43.Bagian ini secara khusus mulai dari ayat 8-10sepertinya memotong ayat 7 dan 11-13. Oleh sebab itu, ada kemungkinan ini merupakan tambahan atau supplemen dari redaktur dalam 19:1-13. Otto berpandangan bahwa ini merupakan redaktur dari postdeuteronomistic dan post-Priestly (Otto 1996:341). Ia menyebutnya sebagai teori "nachexilische Fortschreibung" yaitu sebagai redaktur yang meredaksi teks Deuteronomi, agar dapat masuk ke dalam Pentateuch maupun Hexateteukh. Redaksi post-deuteronomistic dapat terlihat dalam ayat 8-9, sebab terdapat ciri khas dari Deuteronomistic di sana (Otto 1996:341). Ciri post-Priestly terdapat dalam ayat 10, yaitu mengenai darah yang tercurah,ארצךנקי בקרבישפך דםולא. Hal ini menguatkan pandangan bahwa 19:1-13 lebih muda daripada 4:41-43.

7) 19:12 penghukuman terhadap pembunuhan yang berencana, yaitu dengan hukuman mati, yang akan dilakukan oleh Gö’ël, ומתהדםגאלבידאתוונתנואתו משפולקחו.Namun, ini tidak ada dijelaskan dalam 4:41-43.

8) 19:12: tua-tua mengadili pembunuh yang melakukannya dengan sengaja dan terencana, di mana diserahkan kepada penuntut darah. הדם ומתביד גאלאתומשם הדם ונתנוולקחו אתועירוזקניושלחו. Peran tua-tua dan pengadilan lebih berperan, dibandingkan dengan pengadilan keluarga.

9) 4:43 menyebutkan tiga nama kota perlindungan yaitu Bezerרצ׳באת untuk orang Ruben, Ramot ואת־־אמת diGilead untuk orang Gad, dan Golan ואת־גולתמר di Basan untuk orang Manasye. Sementara dalam 19:1-13 tidak menyebutkan nama kota-kota perlindungan. Sementara itu, 19:1-13 tidak ada menyebutkan nama kota perlindungan.

\section{TAFSIRAN}

1. Tafsiran Ulangan 4:41-43

Menurut von Rad (Rad 1966:51-52) dan Weinfeld Ulangan 4:41-43 merupakan interupsi atau gangguan, karena menyimpang dari autobiografi Musa yang dominan dalam Ulangan (Weinfeld 1971:230-33). Senada dengan Driver, bahwa teks ini merupakan tanda jeda dalam narasi, yang kemungkinan didisain 
untuk memisahkan pengantar diskursus 1:6-4:40 dari pasal 5 (Driver 1902:78). Baginya, teks ini merupakan tambahan dari redaktur yang kemudian untuk ekspresikan catatan dalam Ulangan dari trans-Yordan mengenai tiga kota perlindungan. Karena, menurut tradisi ini merupakan rujukan dari janji Musa yang telah telah dilalaikan, sehingga ditambahkan dengan ayat-ayat ini (Driver 1902:78). Weinfeld mengatakan ada kemungkian bahwa ini merupakan tambahan dari pascaDeuteronomic yang kemudian (Weinfeld 1971:233).

Berbeda dengan Cairn, 4:41-43 merupakan addendum (yaitu istilah dalam kontrak atau surat perjanjian yang berarti tambahan klausul atau pasal yang secara fisik terpisah terpisah dari perjanjian pokoknya) dalam pidato, yang menggambarkan bukan dari perkataan Musa, tetapi apa yang diperbuatnya (Cairns 1992:62). Kesejajarannya ditemukan dalam Bilangan 35:9-13; Ulangan 19:1-13, dan Yosua 20:1-9.

Ayat 41-Separated (יבדיל) juga dalam 19:2, 7. Bagi Driver, kata ini tidak mengimplikasikan perpisahan secara fisik, namun sebagai perpisahan yang bertujuan dengan maksud tertentu atau objek tertentu, 10:8; 29:20, 21.; 1:1. —ayat 42 (Driver 1902:79). That the manslayer...in time past, setuju secara lisan dengan 19:3b, 4b, 5b. - ayat 43. Bezer (בער) in the table land. Bezer berada di samping Yosua 20:8; 21:36 (=2 Taw. 6:63, 78); juga disebutkan Batu Moab, sebagai salah satu kota Mesha yang dibangun kembali setelah pemberontakannya (Driver 1902:79). Tempatnya tidak diketahui, tetapi berada di padang gurun (2:8b), ada kemungkinan di perbatasan timur Moab table-land (3:10).- Ramoth in Gilead, Yosua 20:8; 21:38, 36 (=1 Taw. 6:65, 80), menurut Eusebius ia berada 15 mil Roma Timur dari Philedephia (Rabbath Ben Ammon) (Driver 1902:79). Secara umum diidentifikasikan dengan es-Salt; tetapi Dillmann (Kej. 31:54) mengatakan bahwa tempatnya berada di 6 mil ke Utara es-Salt, di reruntuhan el-Jalud.-Golan, Yosua 20:3; 21:27 (=1 Taw. 6:56, 71). Golan diberi nama provinsi Gaulanitis, selalu disebutkan oleh Yosephus. Masa dunia modern disebut sebagai distrik Jolan (atau Jaulan) (Driver 1902:79).

2. Ulangan 19:1-13

Sumber dari Ulangan 19:1-13 adalah berasal dari Kitab Perjanjian, Keluaran 21:12-14, seperti yang pandangan dari von $\operatorname{Rad}(\operatorname{Rad} 1966: 11-29)$, Bernard Levinson (Levinson 1977:3-22), Otto (Otto 1996:112-15), di mana redaktur 19:1- 
13 merevisi, mendaur ulang (Levinson 1977:13-17), amandemen sumbernya (Kel. 21:12-14). Weinfeld berpandangan bahwa latar belakang pemikiran Deuteronomi adalah keadilan sosial, dengan "keagamaan-antroposentris (Weinfeld 1971, 1972:185-86).

Menurut Levinson (Levinson 1977:44-52), Otto (Otto 1996:114), Levinson (Levinson 1977:118) 6 bahwa peraturan atas penetapan enam kota perlindungan dalam Ulangan 19:1-13 adalah berdasarkan sentralisasi kultus atau ibadat dalam pasal 12. Bagi Levinson, program sentralisasi kultus tersebut adalah: sebagai hukum (legislatif) yang mengajukan visi mereka mengenai agama, hukum, sosial, transformasi politik yang menyentuh seluruh area kehidupan masyarakat. Hal ini terlihat dalam masalah kultus, keadilan administrasi politik, kehidupan keluarga, seksualitas, kesejahteraan, keadilan ekonomi dan teologis (Levinson 1977:51).

1-3: kata sambung,'כpada ayat 1, yang diterjemahkah oleh LAI dengan “apabila", sementara ASV, KJV, NAS, NIV, RSV adalah "when”. Menurut von Rad, ini merupakan "hukum kondisional" yang banyak terdapat dalam "Kitab Perjanjian”, di mana ini dikembangkan dalam Timur Dekat Kuno(Ancient Near East) (Rad 1966:3). Namun, hukum ini menjadi populer di Israel setelah penaklukan. Apabila telah dibuat kesepakatan secara legal, maka kata "jika" dibuat bila kesepakatan telah dilanggar, maka akan ada akibatnya atau bahkan ditambahkan juga hukumannya. Kata ini secara khusus banyak dalam kitab Ulangan (Rad 1966:3). Hukumannya adalah Ulangan 4: 27-28.

Ayat 1 ini, merujuk pada tindakan dan perbuatan Tuhan, Allah seperti yang terdapat pada pasal 1-3, yaitu apabila Ia sudah melenyapkan bangsa-bangsa di tanah את־yang dijanjikan-Nya, את־הגויםיהוה אלהידכי־יכרית. Kemudian, bangsa Israel sudah menduduki dan diam di sana ובבתיהםבעריהםוישבתוירשתם Maka, ini menunjukkan bahwa Allah telah memberikan anugerah tanah kepada mereka. Bagi von Rad, inilah dasar bagi bangsa Israel untuk melakukan perintah atau hukum Allah (Rad 1966:16), yaitu menetapkan tiga kota perlindungan עריםשלוש di dalam ayat ke-2. Bagi Mayes, tanah merupakan fokus janji, tempat pahala atas ketaatan, tempat hukum ditaati dan ekspresi status Israel sebagai umat pilihan Tuhan, Allah (Mayes 1981:11). Senada dengan Nelson, tanah merupakan tempat untuk menaati hukum $(6: 1,10 ; 12: 1 ; 16: 18 ; 17: 14 ; 18: 9 ; 19: 1)$ untuk menciptakan keadilan sosial yang digambarkan di dalamnya (Nelson 2004:12).

${ }^{6}$ Sekaligus juga mengubah aspek politik. 
Pengkhususan ${ }^{7}$ tiga kotaלת תבדיל, merupakan bagian dari hukum yang harus dipenuhi. Namun pertanyaan dari Stackert adalah apakah benar ada kota perlindungan (Stackert 2006:23) atau seperti yang diungkapkan oleh von Rad bahwa itu hanyalah sebatas slogan saja dalam bentuk doa perlindungan (prosedur biketeia) (Rad 1966:129)?8 Pandangan von Rad ini tidak disetujui Cairns bahwa kota perlindungan dalam Ulangan 19:1-13 benar-benar ada atau aktual, karena kota-kota tersebut dibuktikan ada di Phoenicia, Syria, Yunani, Roma, Anatolia, Mesir, Syro Palestina (Cairns 1992:16). Mereka ini adalah pelarian (buronan) yang mencari perlindungan ke tempat suci.Cairns berpandangan bahwa kemungkinannya adalah Kedesh di Galilea (utara), Shechem (pusat) dan Hebron (selatan) (Yos.20:7; 19:7-8) (Cairns 1992:16).

Ayat 3, ארצך, 3aitu penetapan (terjemahan LAI) jarak kota perlindungan di dalam tiga bagian wilayah, agar tidak berjauhan. Kata תכין, diterjemahkan oleh ASV, KJV: thou shalt prepare thee the way; NAS: You shall prepare the roads for yourself; NIV: Build roads to them; RSV:you shall prepare the roads. Terjemahan LAI lebih dekat dengan Ibrani yaitu establised. Bagi Mayes, terjemahan RSV memahami bahwa jalan tersebut memberikan akses yang lebih cepat dan mudah ke kota perlindungan (asylum), sehingga ia harus ditetapkan, bahkan NIV lebih tegas yaitu dibangun (ini terjemahan NIV, sekaligus menafsir) (Mayes 1981:286). Tujuannya adalah agar pembunuh dapat melarikan diri (terjemahan LAI) לנוס ke sana. Terjemahannya sama dengan ASV, KJV, NAS, NIV, RSV: flee. Namun, terjemahan hurufiahnya bisa adalah menyelamatkan diri to escape, flee. Dalam ayat 3 ini dijelaskan bahwa kota perlindungan tersebut untuk pembunuh כל־רצח. Mayes mengatakan bahwa kata ini juga digunakan dalam perintah ke-6 dalam dekalog, dan yang diterjemahkan sebagai “kill" oleh RSV (Mayes 1981:286).

4-7: ayat 4 merupakan penegasan kembali dari ayat 1, yaitu mengenai penetapan kota perlindungan.ASV, KJV: And this is the case; NIV: This is the rule; RSV: This is the provision. Terjemahan LAI lebih dekat dengan RSV dan NIV lebih keras lagi yaitu peraturan, sehingga lebih mengarah kepada penafsiran. Ayat 4 ini, menguraikan atau menjelaskan lebih rinci, yaitu pembunuh yang terdapat

${ }^{7}$ Terjemahan LAI, terjemahan ASB, RSV: set apart, KJV: separate; NIV, NAS: set aside. Terjemahannya cukup berbeda dengan LAI. Ibrani arti to sepate self, be exclude from dan divide. Dengan demikian, terjemahan LAI cukup mewakili dari bahasa Ibrani.

${ }^{8}$ Berbeda dengan Robert Coote bahwa yang mengatakan bahwa kota perlindungan untuk mencari tentara bayaran bagi raja (Coote 2015:65-66). 
dalam ayat 3, yaitu dengan tidak disengaja atau dalam bahasa Ibraninya adalah pembunuhan yang tidak diketahui olehnya, sehingga ia melakukannya dengan tidak sengaja. Dengan demikian, motifnya adalah tidak disengaja atau tidak ada maksud khusus dan yang kedua adalah tidak ada motif dendam atau benci terhadap orang tersebut. Ia dapat menyelamatkan dirinya di sana, dengan cara melarikan diri (Gertz 2019:192).

Pada ayat 5, redaktur menjelaskan secara rinci satu contoh kasus mengenai pembunuhan yang tidak diketahui tersebut. Dengan demikian, ia tidak layak untuk memeroleh hukuman mati. Ini menunjukkan bahwa hukum tersebut bukanlah abstrak, melainkan konkret, di mana hukum ini tidak dijelaskan secara rinci dalam Keluaran 21:12-14.

Tujuan dari hukum tersebut terdapat dalam ayat 6 yaitu agar avenger of blood, 'אגga'al, dengan amarah yang mendalam, karena saudaranya terbunuh tersebut tidak langsung membunuhnya tanpa suatu proses pengadilan yang benar. Kata ga'al merujuk pada sanak saudara dari korban yang terbunuh, di mana ia memiliki tanggungjawab untuk melakukan balas dendam terhadap saudaranya (Gertz 2019:192). Mayes mengatakan bahwa situasi ini dipahami sebagai seseorang terlibat di dalam menyebarluaskan pembalasan darah di mana seseorang individu yang terdapat dalam keluarga bertanggungjawab tersebut (Gertz 2019:192). Sementara itu bagi Cairns, "penuntut darah" atau ga'al sangat dekat dengan korban yang ingin menuntut keseimbangan dan membaharui keseluruhan komunal dan hubungan keluarga (bahkan keseluruhan tataran natural), yang terganggu oleh terjadinya pertumpahan darah (Nelson 2004:177). Lebih jauh lagi Cairns berpandangan bahwa ga'al itu digambarkan sebagai Yahweh yang berusaha melepaskan individu, kelompok yang tertindas dari penindas (misalnya Yer. 50:34; Maz. 119:154) dan juga umat secara keseluruhan (Kel. 6:6; Yes. 41:14; Maz. 74) (Cairns 1992:178). Frase "tidak patut untuk mati" משפש־מותאיןולווהכהו נפשכי־רבה (Kat) הדרך, bagi Cairns karena tidak ada putusan (misphat) atas kematian terhadap kasusnya (Cairns 1992:178). Dalam pemikiran Deuteronomic School, misphat atas kematian di dalam kasus pembunuhan yang disengaja terdapat dua tingkatan: 1) pembunuhan adalah musuh dari pikiran Allah seperti yang terdapat dalam Torab; 2) melawan hukum universal yaitu kesadaran manusia dan melawan tataran moral yang implisit dalam penciptaan (Cairns 1992:178).

Ayat 7 mengulangi kembali kataלדיל yaitu mengenai mengkhususkan tiga kota. Kata ini sama dengan ayat 2. Nelson berpandangan bahwa ayat 7 dan 13 merupakan Deuteronomic (Nelson 2004:240). Ayat-ayat ini berbeda karakternya dari interpretasi legal di sekitarnya dalam ayat 4-6, 11-12, dan melampaui isu 
membedakan pembunuhan berencana dan pembunuhan yang tidak disengaja untuk memperluas temperoralnya (bandingkan dengan 12:20). Bagi Nelson, tambahan atas suplemen ini kelihatannya pemicu "pemisahan tiga kota" dalam ayat 7 (Nelson 2004:240). Kota tersebut bagi Cairns adalah yang terdapat dalam 4:43 yaitu Bezer, Ramoth dan Goland (Cairns 1992:178).

8-10: bagian ini sepertinya menginterupsi atau memotong ayat 1-6 dengan 11-13, sehingga Otto mengatakan ini merupakan suplemen dari Post Deuteronomistic dan Post Priestly (Otto 1996:341). Ayat 8-9 merupakan tambahan dari Post Deuteronomistic, karena ciri khas Deuteronomisnya cukup kental, yaitu dengan mengunakan sastra kasuistik. Sedangkan ayat 10 merupakan dari Post Priestly, karena terdapat frase darah yang tercurah ke tanah. Sedangkan bagi Nelson, ayat 8b-9 cukup ganjil dan menganggu, di mana ia muncul dalam tambahan atau suplemen yang kemudian atau belakangan (Nelson 2004:240). Akan tetapi, ini masih dalam bagian Deuteronomic baik dari ragam dan ideologinya (Nelson 2004:240).

Ayat 8 hampir mirip dengan ayat 1, seolah-olah ini merupakan pengulangan, namun ayat 8 ini merupakan pengembangan atau kelanjutan dari ayat 1, יהוה אלהיךואם ירחיב. Menurut Cairns bahwa "perluasan perbatasan" sedang dalam proses seperti yang terdapat dalam 4:43. "Perluasan" muncul berarti gerakan dari barat ke timur (Cairns 1992:178). Roland de Vaux dalam Cairns menyarankan, yaitu (Cairns 1992:178-79): 1) Group "Yusuf', yang telah mengalami pengalaman "Horeb" di bawah Musa, memasuki area yang terletak antara Arnon dan sungai Jabbok. Daerah ini telah diduduki oleh klan Gad-yang kemungkinan tidak ditaklukkan oleh Mesir, tetapi ditobatkan kepada Yahwisme karena dipersembahkan kepada mereka oleh klan Yusuf; 2) pada masa yang lain, setelah penaklukan Kanaan, beberapa unsur klan Ruben mundur ke arah timur ke Transjordan dan bergabung bergabung dengan klan Gad; 3) masih di tahapan "Machir" cabang dari Manasseh, di seberang timur dan menduduki area Transjordan ke utara Jabbok. Cairns mengatakan bahwa jika rekonstruksi ini benar, maka tradisi Ulangan 1-4 merujuk pada pertemuan kelompok Yusuf dengan Gad, di mana Ulangan 19:8 merefleksikan transmigrasi Ruben ke arah timur dan Manasseh (Cairns 1992:178-79). Secara teologis, perpaduan kedua kelompok tersebut merupakan saksi pendudukan Kanaan (meskipun prosesnya komplikasi) sebagai pemberian (Yos. 24:12-13) (Cairns 1992:178-79). Janji ini setidaknya 500 tahun lalu, namun mereka menjadi satu janji נשבע, karena mereka 
satu umat Allah yang secara konstan adalah objek kesetiaan Allah (Cairns 1992:18).

Berbeda dengan Nelson yang berpandangan bahwa perluasan yang terdapat dalam ayat 8-10, kemungkinan berhubungan dengan gagasan penaklukan tanah Kanaan (seperti yang disarankan dalam 7:22) atau aspirasi imperialis (1:7; 11:2224). Kedua 11:22 dan 19:9 juga membuat teroterial masa depan dengan kondisi atau syarat ketaatan (Nelson 2004:241). Dalam 19:8-10, konsep ekspansi adalah lebih daripada jalan penekanan dan ilustrasi prinsip kedekatan daripada definisi prediksi perluasan masa depan. Motivasi penetapan kota perlindungan mengekspresikan perlindungan terhadap umat dari kesalahan kolektif dari "darah yang tidak bersalah" atas pembunuhan (ay. 10; 13 dan 21:8-9). Contoh narasinya terdapat dalam 2 Samuel 21:1-6.

Pada ayat 9, merupakan kelanjutan dari ayat 8, merupakan ciri khas dari Deuteronomistic history yaituרשי־ת, setia: terjemahan LAI; ASV, KJV: keep; NAS: carefully observe; NIV: carefully follow; RSV: careful to keep. Hal ini disertai dengan kata syarat $כ$, sebagai ciri khas dari Deuteronomic; melakukan perintah Tuhan, Allah (terjemahan LAI) מצוךאנכיאשרלעשתה;, mengasihi Tuhan, Allah (terjemahan LAI)את־יהוה אלהדלאהבה:; hidup menurut jalan Tuhan, Allah (terjemahan בדריווללכת), (berjalan dalam jalan Tuhan, Allah). Bagian ini diikuti dengan penambahan lagi tiga kota, sebagai bukti dari ketaatan umat Israel, di mana ini merupakan ciri khas dari Deuteronomic. sementara itu bagi Cairns, ini merupakan sebagai resposn atas ketaatan atas perjanjian (Cairns 1992:179).

Ayat 10 , merupakan ayat yang cukup berbeda, di mana ada penumpahan darah, Ini bukanlah ciri khas dari Deuteronomic history, melainkan sisipan dari redaktur lain. Bagi Otto, ini kemungkinan adalah Post Priestly, sehingga kitab Deuteronomi masuk ke dalam Pentateukh (Otto 1996:341). Redaktur ayat 10 ingin menegaskan bahwa agar tidak terjadi penumpahan darah yang tidak perlu, sehingga tidak terjadi adanya hutang darah (terjemahan LAI); ASV, KJV, NIV, RSV: innocent blood; NAS:the blood of the innocent; עליך דמים(melawan darah, terjemahan hurufiah). Dengan terjemahan hurufiah, maka redaktur ingin mengatakan bahwa melawan darah adalah sama dengan menghancurkan kemanusiaan, dengan menghilangkan nyawa. Bila bagi Prieslty Code darah merupakan bagian dari ritual kultus kepada Tuhan, sehingga ini bagian yang penting dalam kultus.

11-13: Bagi Jan Christian Gertz bahwastruktur kasuistik hukum dalam 19:4b, 5b, 11-12 adalah berdasarkan revisi dari penetapan asylum di dalam Kitab Perjanjian (Gertz 2019:12-14). Implikasinya adalah menginstitusikan asylum dan 
juga hukum kriminal (Gertz 2019:12-14). Gertz mengatakan bahwa "As a result of the transfer of responsibility for homicide to the local judiciary (Torgerichtsbarkeit) it comes in Exod 21:13-14 to the 'replacement of strict liability in favour of liability concerning the responsibililty” (Gertz 2019:12-14). Maksudnya adalah penghukuman atas tindakan tidak lagi bergantung hanya pada konsekuensinya, misalnya adalah fakta internal. Melainkan, pertimbangan atas kondisi seseorang juga harus dipertimbangkan, contohnya adalah fakta internal (Gertz 2019:12-14). Hal ini mengijinkan dan menerima assesmen tindakan dengan fakta eksternal yang sama seperti di dalam kasus yang membedakan antara yang pembunuhan direncanakan dan tidak disengaja. Bagian ini merupakan tugas hukum kasuistik untuk menetapkan secara jelas atau jernih kriteria keputusan yang tepat sama seperti pembedaan atau pengkhususan generalisasi fakta (Gertz 2019:12-14). Gertz menyatakan bahwa ayat 11 ini mengadopsi ayat 4b yang menyatakan cara secara positif; dan pada bagian ini adalah negatif, di mana motif pembunuhannya adalah sesuatu yang direncanakan. Ini bagian dalam dari dirinya, yaitu adanya kebencian serta permusuhan, kemudian ia menyerangnya (Gertz 2019:193).

Dengan demikian,pada ayat 12, pengadilan yang adil berdasarkan pandangan Gertz sedang dalam proses. Pembunuhan yang tidak disengaja atau tidak diketahui diadili untuk mengetahui fakta internal dan eksternalnya. Bagi Nelson, ini dilakukan oleh tua-tua di mana kota perlindungan itu ada, karena merekalah yang mengatur hukum keluarga (21:19-20; 22:15-18; 25:8-9) dan juga mereka bertanggungjawab atas pembunuhan yang tidak dikenal di daerah mereka (21:3-4) (Nelson 2004:241). Nasib pembunuh berkoresponden secara literal terhadap pembunuhan itu sendiri (wämet, "sehingga ia mati" di akhir ayat 11a dan 12) (Nelson 2004:241).

Sedangkan bagi Cairns bahwa ayat 11 meringkaskan pernyataan hukum kasuistik, dimulai dari ayat 4-6, tetapi diinterupsi oleh parenesis (Cairns 1992:179). Kesinambungan (ay. 11-13) menegaskan ulang bahwa hak atas kota perlindungan merupakan bagi pembunuh yang tidak disengaja. Tugas tua-tua adalah jelas berasal dari zaman kuno atau tradisi (21:1-9). Tugas mereka adalah untuk menetapkan peraturan hukum dalam nama Yahweh, di mana Deuteronomic school tidaklah membatalkan aturan "pembalasan hutang darah" (19:6) yang dilakukan oleh tua-tua, melainkan membatasi dan mengatur ulang peraturan tersebut (Cairns 1992:179). Mengesampingkan keberatan dari hak keluarga kuno, ini kemungkinan dari kultus dan berakar dari moral. Secara kritis, para anggota 
keluarga adalah “satu darah". Ini dianggap cukup atau esensi, karena itu darah yang salah seharusnya dibela oleh keluarga. Secara moral, tugas penuntut darah secara khusus dan dipaksa untuk bertanggungjawab atas keluarganya. Tanggungjawab ini untuk menegakkan kehidupan dan kematian dalam keluarga, di mana ini merupakan kehidupan kecil dari umat perjanjian (covenant) (Cairns 1992:180).

Ayat 13, mirip seperti ayat 10 mengenai bagaimana seseorang melawan darah, yaitu dengan mengambil nyawa manusia. Ini berkaitan dengan sumber Priestly, sehingga ada kemungkinan ini merupakan redaktur dari Post-Priestly, sehingga bagian ini masuk ke dalam Penteteukh (Otto 1996:341). Maka, keadilan harus ditegakkan, sehingga orang yang melakukan kejahatan kemanusiaan harus memeroleh hukuman yang setimpal atas perbuatannya. Dengan demikian, Nelson mengatakan bahwa implikasinya adalah seseorang mungkin tidak dapat mengantikan hutang darah dengan uang untuk eksekusianya (Bil. 35:31) (Nelson 2004:241).

\section{TEOLOGI KEADILAN BERDASARKAN KOTA PERLINDUNGAN}

1. Keniscayaan tempat perlindungan

Tempat perlindungan pada masa Ulangan 4:41-43 dan 19:1-13 merupakan suatu kebutuhan. Tujuannya adalah agar tidak terjadi darah yang tertumpah dengan sia-sia, yang dilakukan oleh go'el. Karena, kehidupan itu penting bagi Ulangan 4:41-43 dan 19:1-13 (Weinfeld 1972:233-46).

\section{Reformasi hukum}

Reformasi hukum telah dilakukan redaktur 19:1-13, yaitu hukum keluarga (go'el) dengan hukum terpusat. Proses pengadilan untuk melihat atau mengecek bukti dari pembunuhan, dan bukan dilakukan atas balas dendam saja (Levinson 1977:144-57). Prosesnya adalah dengan tidak hanya melihat fakta eksternal, tetapi juga internal, yaitu motifnya. Hal ini dilakukan oleh tua-tua maupun hakim setempat. Ini merupakan bagian dari reformasi hukum (Weinfeld 1972:233-46). 
3. Penegakan Hak Asasi Manusia untuk hidup

Keadilan menurut kota perlindungan ini adalah nyawa manusia yang tidak bersalah adalah sangat berharga (Weinfeld 1972:233-46). Inilah yang sangat penting bagi redaktur Ulangan, yaitu hak asasinya harus diperjuangkan. Inilah keadilan yang harus diterima oleh manusia dengan proses hukum yang adil. Ukurannya adalah hukum yang adil, di mana orang yang melarikan diri atas pembunuhan yang tidak disengaja dapat diadili di sana berdasarkan hukum yang berlaku. Sebab, apabila ia tidak berada dalam kota perlindunga, maka go'el dapat membalas hutang darah dengan membunuhnya tanpa melalui proses pengadilan yang resmi, meskipun ia tidak bersalah.

4. Keharmonian antara hukum kultus dan hukum sosial

Redaktur Ulangan mengintegrasikan antara hukum kultus dan hukum sosial dalam masyarakat. Dasar hukum sosial tersebut berdasarkan hukum kultus. Inilah salah satu bagian dari reformasi Deuteronomic (Levinson 1977:144-57). Dasarnya adalah mengasihi Allah, sama seperti mengasihi diri sendiri. Wujudnya adalah keadilan sosial dalam umat Israel dalam bentuk hukum.

\section{KESIMPULAN}

Sumber Ulangan 19:1-13 adalah berasal dari Kitab Perjanjian, Keluaran 21:12-14, di mana meredaksi dan editnya untuk menjawab permasalahan atau kebutuhan pada amsa zamannya. Teks 4:41-43 merupakan redaktur yang belakangan yaitu pada masa Persia, sementara itu 19:1-13 lebih muda daripada 4:41-43, yaitu masa akhir kerajaan Selatan, dan masa Neo-Babilonia.

Kota perlindungan merupakan tempat perlindungan bagi orang yang melakukan pembunuhan yang tidak diketahui atau tidak disengaja olehnya. Tujuannya agar ia tidak dihukum mati oleh go'el, sehingga darah bersalah tertumpah dan kehidupan tidak lenyap. Inilah keadilan yang terdapat menurut kota perlindungan. Dengan demikian, teologi keadilan menurut kota perlindungan adalah keniscayaan tempat perlindungan, reformasi hukum, penegakan hak asasi manusia untuk hidup, dan keharmonian antara hukum kultus dan sosial. 


\section{DAFTAR PUSTAKA}

Barnabas Ludji. 2009. Pemahaman Dasar Perjanjian Lama 1. Bandung: Bina Media Informasi.

Blommendaal, J. 1985. Pengantar Kepada Perjanjian Lama. Jakarta: BPK Gunung Mulia.

Cairns, Ian. 1992. Deuteronomy: Word and Presence (International Theological Commentary). Grand Rapids: Eerdmans.

Coote, Robert. 2015. Sejarah Deuteronomistic: Kedaulatan Dinasti Atas Wilayah Kesukuan Israel. Jakarta: BPK Gunung Mulia.

Driver, S. R. A. 1902. Critical and Exegetical Commentary On Deuteronomy. Edinburgh: T\&T Clark.

Feinberg, Charles lee. 1947. "Charles Lee.” Bibliotheca Sacra 103.

Gerhard von Rad. 1966. Deuteronomy. Philadelphia: The Westminster Press.

Gertz. 2019. "Deuteronomy and the Covenant Code and Their Cultural and Historical Contexts. Hermeneutics of Law and Innerbiblical Exegesis." Zeitschrift Für Altorientalische Und Biblische Rechtsgeschichte / Journal for Ancient Near Eastern and Biblical Law. doi: 10.13173/zeitaltobiblrech.25.2019.0187.

Greenberg, Moshe. 1959. “The Biblical Conception of Asylum.” Journal of Biblical Literature. doi: 10.2307/3264937.

Hardiman, F. Budi. 2015. Seni Memahami: Hermeneutik Dari Schleiermacher Sampai Derrida. edited by Widiantoro. Yogyakarta: Kanisius.

Krentz, Edgar. 1975. The Historical-Critical Method. edited by G. M. Tucker. Philadelphia: Fortress Press.

Levinson, Bernard M. 1977. Deuteronomy and the Hermeneutics of Legal Innovation. Oxford: Oxford University Press.

Mattison, Kevin. 2016. "MWSBL Student Paper Prize Bloodguilt and Asylum in Deuteronomy and the Holiness Legislation." Conversations with the Biblical World 36:29-45.

Mayes, A. D. H. 1981. The New Century Bible Commentary Deuteronomy. Grand Rapids: Eerdmans. 
Nelson, Richard. 2004. Old Testament Library: Deuteronomy. Louisville: Westminster John Knox.

Otto, Eckard. 1996. "Kontinuum Und Proprium: Studien Zur Sozial-Und Rechtsgesichte Den Alten Orients Und Des Alten Testaments." in The Preexilic Deuteronomy as a Revision of the Covenant Code. Wiesbaden: Harrasowitz Varlag.

Rad, Gerhard Von. 1966. The Old Testament Library: Deuteronomy. Philadelphia: The Westminster Press.

Stackert, Jeffrey. 2006. "Why Does Deuteronomy Legislate Cities of Refuge? Asylum in the Covenant Collection (Exodus 21:12-14) and Deuteronomy (19:1-13)." Journal of Biblical Literature 125(1):23-49. doi: 10.2307/27638345.

Stackert, Jeffrey. 2016. "Political Allegory in the Priestly Source-the Destruction of Jerusalem, the Exile and Their Alternatives." in The Fall of Jerusalen \& the Rise of the Torah, edited by P. Dubousky. Tubingen: Mohr Siebeck Tubingen.

Thomas, Romer. 2007. The So-Called Deuteronomistic-A Sociological, Historical and Literary Introduction. London: T \& T Clark.

Weinfeld, Moshe. 1971. The Anchor Bible: Deuteronomy 1-11: A New Translation with Introduction and Commentary. New York: The Anchor Bible Doubleday.

Weinfeld, Moshe. 1972. Deuteronomy and Deuteronomic School. Oxford: Oxford University Press.

Wellhausen, Julius, J. Sutherland Black, Allan Menzies, and William Robertson Smith. 2013. Prolegomena to the History of Israel. Cambridge: Cambridge University Press. 